\title{
With \& Without the Tracks: How Railroad Access Impacts Gas Price Elasticity
}

\author{
Alex Kaechele \& David J.G. Slusky \\ Department of Economics, University of Kansas, Lawrence, U.S.A.
}

Slusky (corresponding author): Department of Economics, University of Kansas, david.slusky@ku.edu,785-864-1954.

Acknowledgements: The authors thank Dietrich Earnhart, Donna Ginther, Tsvetan Tsvetanov, and Brian Staihr for their comments and suggestions. Partial funding for this project was from the Department of Economics at the University of Kansas. 
With \& Without the Tracks: How Railroad Access Impacts Gas Price Elasticity

Since 2011, gas prices have fallen $43 \%$, raising the question how different communities adjust their vehicle miles travelled. Data from the National Household Travel Survey's EPA fuel economy database, and the Energy Information Administration database are used to measure consumers' driving elasticity to changes in gas prices. We find no significant difference between the price elasticity of individuals in cities with rail access and those without.

Furthermore, we are able to rule out a gas price elasticity in those with rail that is greater than 0.61 , suggesting that rail access does not make a consumer demand elastic.

Keywords: gas prices, vehicle miles traveled, public transportation, commuting, elasticity

Subject classification codes: D12, L71, Q35, R41

\section{Introduction}

Since 2011, average gas prices have declined $43 \%$ from over $\$ 4.00$ /gallon to $\$ 2.28$ in July 2017 (Vehicle Technologies Office, 2016). This raises the question as to whether such a shock will cause drivers with rail access to substitute from rail back to driving more than those without rail access. This answer has implications towards creating an optimal gas tax policy, as policy makers fear that raising gas taxes will have a disproportionate impact on individuals living in rural areas or in areas without access to rail transportation.

The gas tax has benefits such as paying for infrastructure and internalizing external costs of gasoline. For many states, gasoline taxes are used as a "user tax" and the revenue goes towards the maintaining and building roads. However, many states with umbrella debt limits are dipping into the gas tax revenues to finance debts (Denison, Hackbart, \& Moody, 2008). Additionally, transportation costs have been increasing as more roads are built, thus increasing maintenance costs over time 
(Winston \& Langer, 2006). Furthermore, gas tax revenues have fallen as the taxes are infrequently increased nor indexed to inflation, and cars have become more fuel efficient (Marion \& Muehlegger, 2011). The combination of these problems means funding alternatives need to be found to maintain the current level of transportation spending.

Another reason governments use gasoline taxes is to force individuals to internalize the external costs of using gasoline. Using gasoline imposes external costs both locally and globally. Carbon dioxide, a byproduct of burning gasoline, is a greenhouse gas which negatively impacts farmers, coastal residents, and others (Ahsan \& Brandt, 2014). Additionally, gasoline can pollute locally from gas leakages and contribution to smog (Kampa \& Castanas, 2008). Gasoline taxes can address these externalities, as well as others related to traffic congestion and automobile accidents (Parry \& Small, 2005). Thus, there may be some benefit to using gasoline taxes to force consumers to realize the social cost of driving gas cars.

Below, we test our hypothesis utilizing recent variation in gas prices interacted with whether a city has rail. Although we expect drivers with rail access would be more elastic than those without, since we consider trains and cars as substitutes in transportation methods, we find no difference in the elasticities of the two groups. Furthermore, we can rule out that MSAs with rail access are elastic at all (i.e., |elasticity $\mid>1$ ) despite the availability of a substitute.

\section{Data and Methodology}

We conducted a household level analysis using the dataset complied by Li, Linn and Muehlegger (2014) (hereafter LLM) for the years 1995, 1996, 2001, and 2002. The dependent variable, vehicle miles traveled, is recorded by the EPA fuel economy database from the vehicles' odometers. Price data came from the Energy Information 
Administration and gasoline tax data was collected from the Federal Highway

Administration.

The equation below shows our regression framework.

$$
\begin{aligned}
\ln \left(\text { VMT }_{\text {imt }}\right)= & \alpha+\beta \ln \left(\text { Price }_{m t}\right)+\gamma \text { Rail }_{m}+\delta \ln \left(\text { Price }_{m t}\right) * \text { Rail }_{m}+\theta X_{i m t}+\rho Y_{m} \\
& +\delta Z_{t}+\varepsilon_{i m t}
\end{aligned}
$$

$V M T$ is the household sum of average daily vehicle miles traveled for individual $i$ living in MSA $m$ in month and year $t$. Price is the average gas price for that MSA-monthyear. Rail is a dummy for whether that MSA has heavy commuter rail access, as determined by the Federal Highway Administration. Rail access means the household location has access to short distance rail and subways used to get from place to place within a city. For example, the DC Metro and the Chicago "L" are considered heavy rail, but solely having Amtrak service is not (National Household Travel Survey, 2009). $X$ is a vector including person/household controls: number of individuals, adults, and drivers; household income, and age and education of reference person. $Y$ is a vector including location controls: state fixed effects, MSA size, worker density of MSA, population density of MSA, and whether the area is classified as "second city," "suburban," "town and country," or "urban.". ${ }^{1}$ Finally, $Z$ is a vector of year fixed effects and month fixed effects. All of this follows LLM. Our main contribution in this paper beyond their work is to add the interaction term between log gas prices and whether a city has rail. $\delta$ is therefore our coefficient of interest.

Figure 1 maps shows the cities with and without rail access.

\section{Figure 1: Cities With and Without Rail Access}

\footnotetext{
${ }^{1}$ MSA identifiers are not unavailable in the dataset so we could not include a MSA fixed effect.
} 


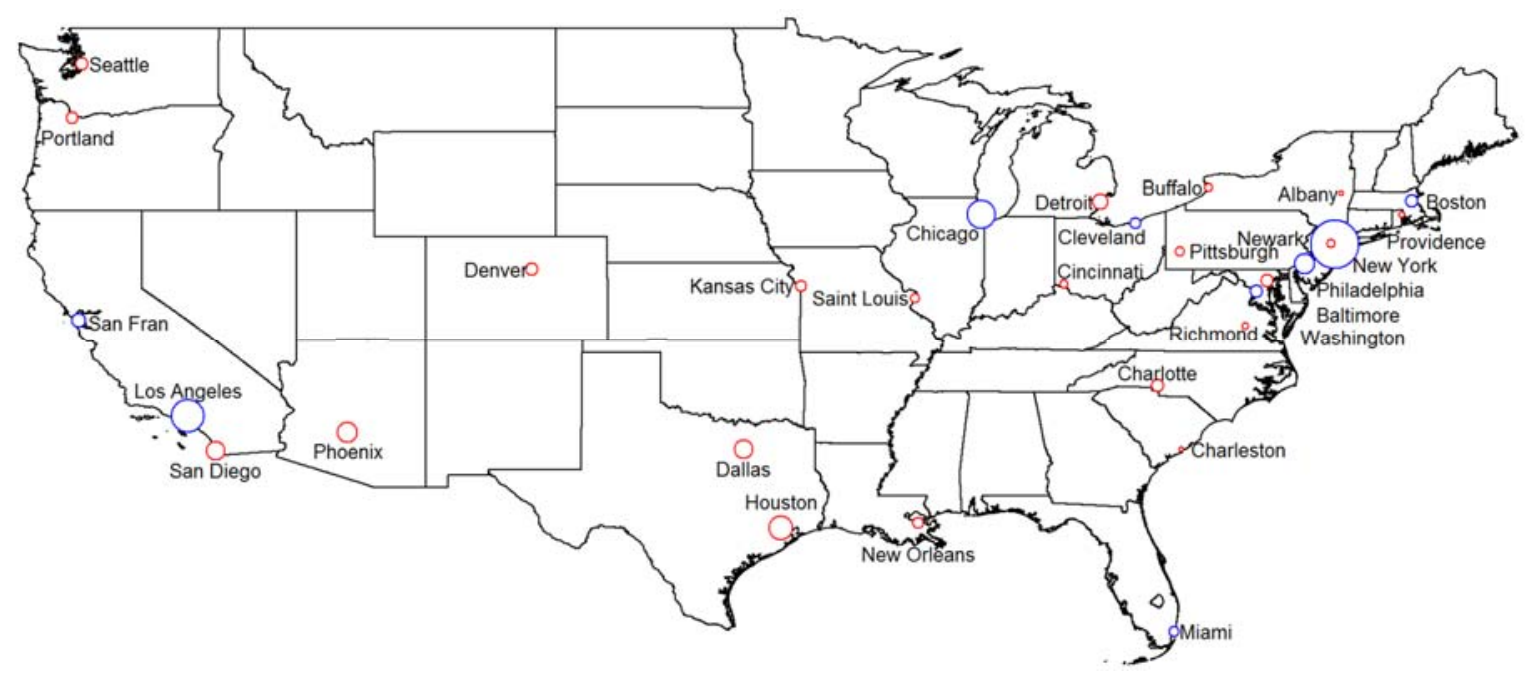

Notes: Cities with rail access are colored blue and cities without rail access are colored red. The size of the dot is proportional to the population of the city.

There is a reasonable distribution of cities across the US, with each broad region of the US having some cities with rail and some without, and also larger and smaller cities with and without rail.

Gasoline prices (pretax prices plus taxes) should be considered exogenous per LLM, which tests the erogeneity of gas prices in two different approaches. The first test was to compare states with high vs low tax rates; they find no difference in demographic variables, a small difference in divers per capita, and no statistical difference in probability of electing a Democratic versus Republican governor or house representative. The second test they conducted was to see whether "changes in economic or political variables predict state gasoline changes," and found no evidence supporting it.

\section{Results}

Table 1 displays the summary statistics of variables in our sample stratified by rail access. 
Table 1: Summary Statistics

\begin{tabular}{|c|c|c|c|c|c|c|}
\hline \multirow[b]{2}{*}{ Variable } & \multicolumn{2}{|c|}{$\begin{array}{c}\text { Rail } \\
(\mathrm{N}=3,914)\end{array}$} & \multicolumn{2}{|c|}{$\begin{array}{c}\text { No Rail } \\
(\mathrm{N}=24,389)\end{array}$} & \multirow[b]{2}{*}{ Difference } & \multirow[b]{2}{*}{ P-value } \\
\hline & Mean & SD & Mean & SD & & \\
\hline Rail & 1 & 0 & 0 & 0 & 1 & \\
\hline Tax-excl. gas price & 1.088 & .1351 & 1.058 & .1205 & .0297 & 0.182 \\
\hline Gas tax & .4425 & .0581 & .4818 & .0466 & -.0393 & 0.010 \\
\hline Household size & 2.452 & 1.292 & 2.376 & 1.257 & .0760 & 0.027 \\
\hline Number of drivers & 1.766 & .6807 & 1.753 & .6480 & .0130 & 0.531 \\
\hline Number of adults & 1.841 & .6603 & 1.792 & .6015 & .0486 & 0.010 \\
\hline Number of workers & 1.257 & .8994 & 1.200 & .9045 & .0574 & 0.054 \\
\hline Age of reference & 51.83 & 15.58 & 51.95 & 16.27 & -.1151 & 0.798 \\
\hline \multicolumn{7}{|l|}{ person } \\
\hline Household income & 11.73 & 5.118 & 9.557 & 4.863 & 2.171 & $<0.001$ \\
\hline Education of ref. & 3.338 & 1.183 & 3.060 & 1.148 & .2781 & $<0.001$ \\
\hline \multicolumn{7}{|l|}{ person } \\
\hline MSA size & 4.974 & .2006 & 3.326 & 1.710 & 1.648 & $<0.001$ \\
\hline Worker density & 2051 & 1713 & 1090 & 1276 & 960.8 & $<0.001$ \\
\hline Population density & 5510 & 5639 & 2887 & 4047 & 2623 & $<0.001$ \\
\hline Second City & .1776 & .3822 & .2498 & .4329 & -.0722 & 0.015 \\
\hline Suburban & .4062 & .4912 & .2454 & .4303 & .1609 & $<0.001$ \\
\hline Town and Country & .2210 & .4150 & .4454 & .4970 & -.2244 & $<0.001$ \\
\hline Urban & .1952 & .3964 & .0594 & .2364 & .1358 & 0.001 \\
\hline
\end{tabular}


Note: P-values are calculated by regressing the variable in question on a dummy variable for rail, with robust standard errors clustered at the state level.

Cities with rail access are clearly different from cities without rail access. With $99 \%$ confidence, households in cities with rail have more adults, workers, and individuals; reference persons with higher income and education; and are more likely to be urban/suburban and less likely to be rural. This systematic differences support the hypothesis that gas price elasticity should be different between individuals living in these two types of cities.

Table 2 contains our main results. 
Table 2: Main Results

\begin{tabular}{|c|c|c|c|}
\hline & (1) & (2) & (3) \\
\hline \multirow[t]{2}{*}{ Log Gas Price } & $-0.393^{* * *}$ & $-0.391 * * *$ & $-0.316^{* *}$ \\
\hline & $(0.132)$ & $(0.133)$ & $(0.151)$ \\
\hline \multirow[t]{2}{*}{ Rail } & & -0.027 & 0.200 \\
\hline & & $(0.035)$ & $(0.190)$ \\
\hline \multirow[t]{2}{*}{ Log Gas Price* Rail } & & & -0.149 \\
\hline & & & $(0.118)$ \\
\hline Observations & 28,303 & 28,303 & 28,303 \\
\hline R-Squared & 0.450 & 0.450 & 0.450 \\
\hline
\end{tabular}

Notes: The dependent variable is log vehicle miles traveled. Robust standard errors are clustered by state. Covariates include: quadratics in numbers of individuals, drivers, and adults, in the household, and in log age of the reference person; household income, education of reference person, MSA size, worker density of MSA, population density of MSA, whether the area is a "second city," "suburban," "town and country," or "urban," and year, month and state fixed effects. Weighted using survey weights. $* * * \mathrm{p}<0.01, * *$ $\mathrm{p}<0.05,{ }^{*} \mathrm{p}<0.1$.

Column 1 shows the gas price elasticity on vehicle miles traveled without considering whether the individual has rail access. Here we see a statistically significant 
inelastic demand for miles travel with a coefficient of -0.39 . In Column 2, the regression also includes a rail dummy variable, as in LLM, and matches their result exactly. Notice that the coefficient on the rail dummy (not reported in their paper) is not statistically significant and very small in magnitude.

Column 3 has the rail dummy variable as well as a gas price and rail dummy interaction. Although our hypothesis was that those with rail access would be more elastic to a change in gas prices than those without rail access, and the coefficient on the interaction term is negative (i.e., more elastic), it is not statistically significant.

Using the point estimate and standard errors we are able to rule out with $95 \%$ confidence an elasticity for MSAs with rail access less than $-0.61 .^{2}$ This implies that even those with rail access are still inelastic.

\section{Conclusion}

We find that MSAs with rail access are not statistically different in their driving elasticities than those without rail access. Additionally, the regression results rule out those with rail access of having a greater than -0.61 elasticity. This implies any policy to raise the gas tax should not have any disproportionate impact on vehicle miles traveled of cities with rail access compared to those without.

While the result that MSAs with rail access have the same gas price elasticities as those without rail access is surprising, there are a few explanations. It is possible that rail ticket prices also rose during this period of time limiting the substitution from car to rail. Individuals may also prefer the privacy and flexibility of a car over riding a train making the two less substituable. Additionally, the first/last mile problem (i.e., individuals may not have easy access from their home to the train station or from the

${ }^{2}-0.316-1.96 *-0.149=-0.61$ 
train station to their destination), may also make people less likely to take the train (

Wang \& Odoni, 2014). Finally, it may be that individuals have already optimized for their commute and so the results are indicative of a small extensive margin.

\section{References}

Ahsan, D., \& Brandt, U. (2014). Climate Change and Coastal Aquaculture Farmers' Risk Perceptions: Experiences From Bangladesh and Denmark. Journal of Environmental Planning and Management, 58(9): 1649-1665.

Denison, D., Hackbart, M. \& Moody, M. (2008). Intrastate Competition for Debt Resources. Public Finance Review, 37(3): 269-288.

Kampa, M., \& Castanas E. (2008). Human Health Effects of Air Pollution. Environmental Pollution, 151(2): 362-367.

Li, S., Linn, J., \& Muehlegger, E. (2014). Gasoline Taxes and Consumer Behavior. American Economic Journal: Economic Policy, 6(4): 302-342.

Marion, J., \& Muehlegger, E. (2011). Fuel Tax Incidence and Supply Conditions. Journal of Public Economics, 95(9): 1202-1212.

National Household Travel Survey (2009). Derived Variables Description. http://nhts.ornl.gov/2009/pub/DerivedAddedVariables2009.pdf

Parry, I., \& Small, K. (2005). Does Britain or the United States Have the Right Gasoline Tax? The American Economic Review, 95(4): 1276-1289.

Vehicle Technologies Office (2016). Average Historical Annual Gasoline Pump. https://energy.gov/eere/vehicles/fact-915-march-7-2016-average-historicalannual-gasoline-pump-price-1929-2015.

Winston, C., \& Langer, A. (2006). The Effect of Government Highway Spending on Road Users' Congestion Costs. Journal of Urban Economics, 60(3): 463-483.

Wang, H., \& Odoni, A. (2014). Approximating the Performance of a "Last Mile" Transportation System. Transportation Science, 50(2): 659-675. 